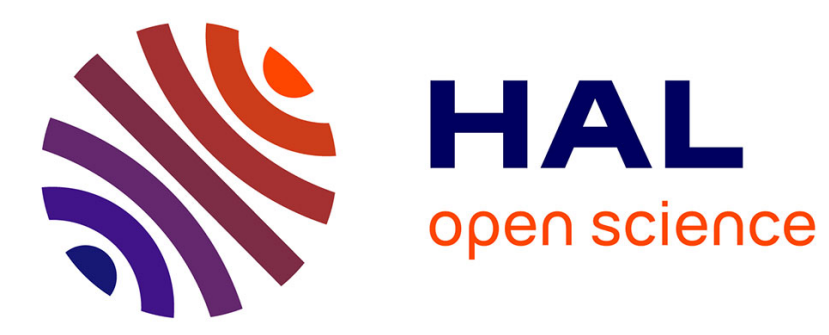

\title{
Room-Temperature Pd-Catalyzed Synthesis of 1-(Hetero)aryl Selenoglycosides
}

Mingxiang Zhu, Mouad Alami, Samir Messaoudi

\section{To cite this version:}

Mingxiang Zhu, Mouad Alami, Samir Messaoudi. Room-Temperature Pd-Catalyzed Synthesis of 1-(Hetero)aryl Selenoglycosides. Organic Letters, 2020, 22 (16), pp.6584-6589. 10.1021/acs.orglett.0c02352 . hal-03036512

\section{HAL Id: hal-03036512 \\ https://hal.science/hal-03036512}

Submitted on 2 Dec 2020

HAL is a multi-disciplinary open access archive for the deposit and dissemination of scientific research documents, whether they are published or not. The documents may come from teaching and research institutions in France or abroad, or from public or private research centers.
L'archive ouverte pluridisciplinaire HAL, est destinée au dépôt et à la diffusion de documents scientifiques de niveau recherche, publiés ou non, émanant des établissements d'enseignement et de recherche français ou étrangers, des laboratoires publics ou privés. 


\title{
Room Temperature Pd-Catalyzed Synthesis of 1-(Hetero)aryl Selenoglycosides
}

\author{
Mingxiang Zhu, ${ }^{\mathrm{a}}$ Mouad Alami, ${ }^{\mathrm{a}}$ and Samir Messaoudi ${ }^{\mathrm{a}}$ \\ ${ }^{a}$ BioCIS, Univ. Paris-Sud, CNRS, University Paris-Saclay, Châtenay-Malabry, France \\ Supporting Information Placeholder
}

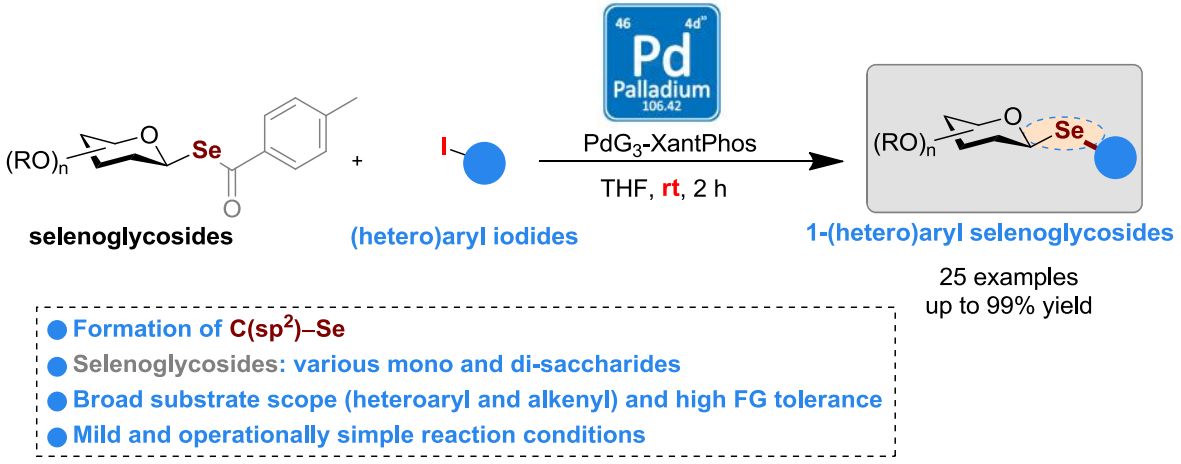

ABSTRACT: A general protocol for functionalization of anomeric selonate anion at room temperature has been reported. By using PdG3 XantPhos catalyst, the cross-coupling between the in situ generated glycosyl selenolate and a broad range of (hetero)aryl and alkenyl iodides furnished a series of functionalized selenoglycosides in excellent yields with a perfect control of the anomeric configuration.

1-selenoglycosides constitute a privileged class of glycosides and are considered as a one of the promising family of glycomimetics with some significant enhanced in vivo stabilities. Although it has been less explored in carbohydrate chemistry, they received during the last years an increasing attention due to their versatile biologically significant applications ${ }^{[1]}$ including ligand based-therapeutics to carbohydrate-binding proteins, ${ }^{[2]}$ X-ray crystallographic studying of carbohydrate-protein complexes, ${ }^{[3]}$ and ${ }^{77} \mathrm{Se}-\mathrm{NMR}$ spectroscopy handles for carbohydrate-proteine interactions (compound $\mathbf{1}$, Figure 1) ${ }^{[4]}$ Since the discovery of the first selenoglycoside (2) (Figure 1) in rat and human urine as a hepatic Se-metabolite, ${ }^{[5]}$ the design and synthesis of bioactive seleglycosides have gained more attention within the chemistry community. Selected biologically active 1-selenoglycosides are represented in Figure 1, including Se-KRN7000 (3) ${ }^{[6]}$ as analogue of the potent immunostimmulant $\alpha$-GalCer (KRN7000), the antiinvasive and anti-metastatic organoselenium glycoconjugate $(4)^{[7]}$ which targets multiple kinases in preclinical models, the di- $\beta$-D-galactopyranosyl-diselenide $(\mathbf{5})^{[8]}$ with an antitumoral activity and ligand for lectin and the selenoglycoside AcSG $(6)^{[9]}$ as activator of phosphatases 1 and 2-A, two proteins involved in cancers. From the organic synthesis point of view, selenoglycosides have been investigated as unique glycosyl donors in glycosylation reactions. ${ }^{[10]}$

The usual approach employed for the synthesis of selenoglycosides relies on the use of selenium sources in the nucleophlic substitution of 1-halosugars ${ }^{[11]}$ (Figure 2A) or a nucleophilic opening of the Danishefsky 1, 2-anhydro sugars (Figure 2B). ${ }^{[12]}$ Azidophenylselenation of glycals, ${ }^{[13]}$ was also as an efficient method to prepare selenoglycosides bearing an azido group at

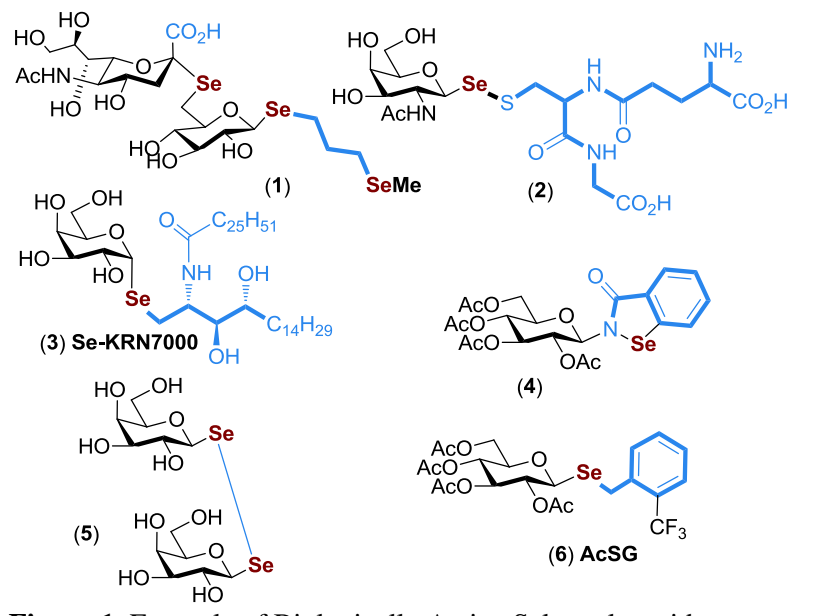

Figure 1. Example of Biologically Active Selenoglycosides

the C2-position. However, selenium nucleophiles such as arylselenols are not commercially available and must be prepared usually from potassium selenocyanate $(\mathrm{KSeCN})$ and aryliodonium salts followed by the reduction of the $\mathrm{Se}-\mathrm{CN}$ bond in the presence of reducing agent such as $\mathrm{NaBH}_{4} \cdot{ }^{[11 \mathrm{e}]}$ Another major drawback of this approach is the use of toxic, unstable and unpleasantly smelling arylselenols and diselenides.

Ando, Ishihira and co-workers ${ }^{[14]}$ developed an elegant method to prepare various alkyl Se-glycosides by an in situ generating of an anomeric selenolate anion from $\beta-p$ methylbenzoylselenoglycoside, which reacts with alkyl halides 
$(\mathrm{Cl}, \mathrm{Br}$ and $\mathrm{I})$ to yielde selenoglycosides with retention of the anomeric stereochemistry (Figure 2C). However, this method is limited to only alkyl halides. Only one example for the synthesis

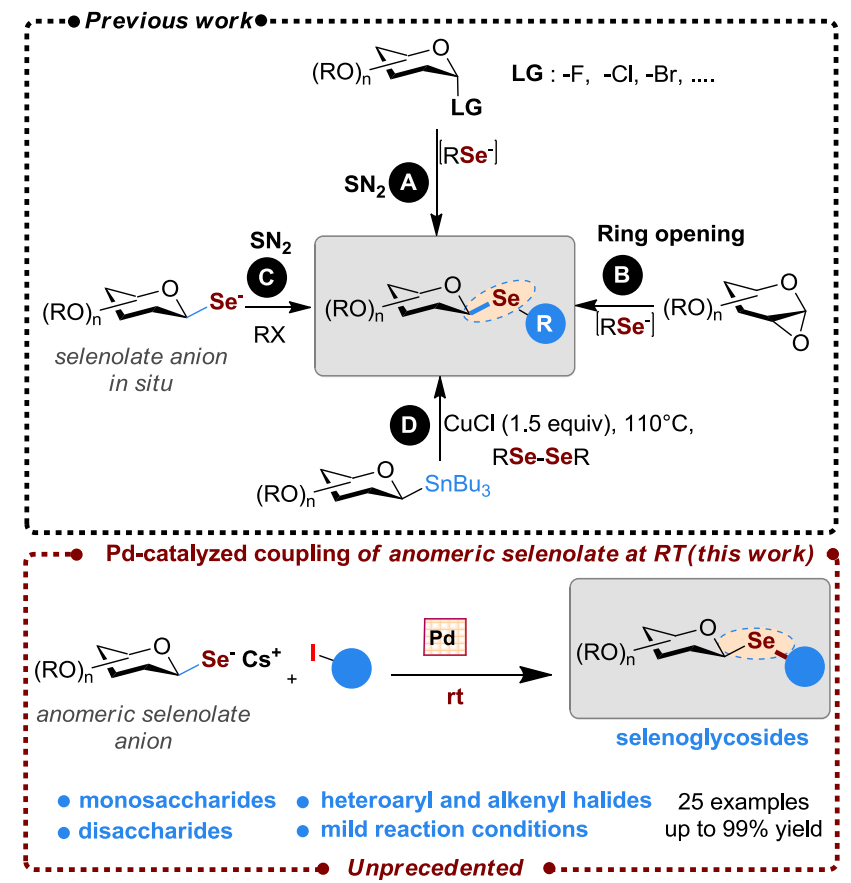

Figure 2. Strategies for the synthesis of selenoglycosides.

of aryl-selenoglycoside was reported by this approach using the highly activated 4-nitro fluorobenzene substrate in a nucleophilic aromatic substitution reaction $\left(\mathrm{SN}_{\mathrm{Ar}}\right)$.

Recently, Walczak and co-workers ${ }^{[1 \mathrm{a}]}$ described an original approach (Path D) to the preparation of selenoglycosides based on the coupling of glycosyl stannane with symmetrical diselenide in the presence of 1.5 equiv of $\mathrm{CuCl}$. This method is clearly attractive. However, it necessitates high reaction temperature $\left(110{ }^{\circ} \mathrm{C}\right)$ and requires the use of the toxic alkyltin species in a multi-steps approach to prepare the starting 1stanylated sugars.

To fully harness the potential of this class of carbohydrates there is a strong impetus to develop mild and general reactions for the synthesis of complex selenoglycosides. As part of our interest to explore the reactivity of sugars under transitionmetal catalysis, ${ }^{[15]}$ combined with the lack of general method to Se-glycosides, we became interested in developing an efficient and simple Pd-catalyzed cross-coupling protocol for the preparation of (hetero)aryl-selenoglycosides which may occur under mild reaction conditions. Catalytic methods generally avoid the use of harsh reaction conditions and maintain the compatibility with most organic functions. However, the use of selenium nucleophilic partners in $\mathrm{Pd}(0)$-cross couplings is highly challenging as they are well known to be poison of the catalyst through the formation of off-cycle complexes. ${ }^{[16]}$ Herein we report a direct and programmable synthesis of selenoglycosides via Pd-G3-XantPhos catalyzed coupling of an in situ generated anomeric selenolate-anion with various (hetero)aryl and alkenyl iodides at room temperature.

In the first part of this study, the coupling of tetra- $O$-acetylated $\beta$ - $p$-methylbenzoylselenoglycoside 1 a $(1$ equiv) with $p$ iodoanisole 2a (2 equiv) was used as a model study, and various reaction conditions were examined. Representative results are summarized in Table 1 and the full optimization is reported in SI. The coupling of 1a with $\mathbf{2 a}$ was first investigated under our previously reported protocol for the coupling of thiosugars $^{[17]}$ using PdG3-XantPhos precatalyst (10 mol\%).
$\mathrm{Cs}_{2} \mathrm{CO}_{3}$ (3 equiv) and piperazine (1.2 equiv) were added and the

Table 1 Optimization of the Coupling Reaction of $1 \mathbf{a}$ with $\mathbf{2} \mathbf{a}^{a}$

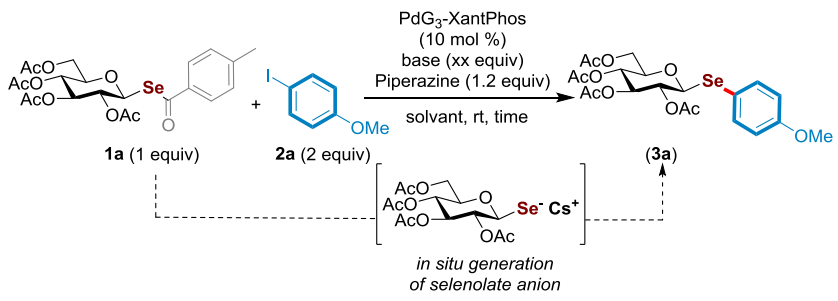

\begin{tabular}{|c|c|c|c|c|}
\hline entry & base & solvant & Time (h) & 3a $(\%)^{b}$ \\
\hline 1 & $\mathrm{Cs}_{2} \mathrm{CO}_{3}$ & THF & 12 & 95 \\
\hline 2 & $\mathrm{Cs}_{2} \mathrm{CO}_{3}$ & THF & 12 & $81^{c}$ \\
\hline 3 & $\mathrm{CsF}$ & THF & 2 & 83 \\
\hline 4 & $\mathrm{NaOAc}$ & $\mathrm{THF}$ & 2 & 65 \\
\hline 5 & $\mathrm{Cs}_{2} \mathrm{CO}_{3}$ & dioxane & 2 & 95 \\
\hline 6 & $\mathrm{Cs}_{2} \mathrm{CO}_{3}$ & DCE & 2 & 83 \\
\hline 7 & $\mathrm{Cs}_{2} \mathrm{CO}_{3}$ & DMF & 2 & 89 \\
\hline 8 & $\mathrm{Cs}_{2} \mathrm{CO}_{3}$ & THF & 1 & 80 \\
\hline 9 & $\mathrm{Cs}_{2} \mathrm{CO}_{3}$ & THF & 2 & 95 \\
\hline
\end{tabular}

${ }^{a}$ A sealable tube was charged with $\beta$ - $p$-methylbenzoylselenoglycoside 1a (1 equiv, $0.1 \mathrm{mmol}$ ), iodoanisole 2a (2 equiv), [PdG3-XantPhos precatalyst (10 mol \%), piperazine (1.2 equiv), base ( 3 equiv) in dry and degassed solvent $(0.1 \mathrm{M}) .{ }^{b}$ Yield of isolated product. ${ }^{c} 5 \mathrm{~mol} \%$ of PdG3-XantPhos were used.

reaction was performed in THF at room temperature (Table 1, entry 1). By the action of piperazine and $\mathrm{Cs}_{2} \mathrm{CO}_{3}$, the $\beta$ selenolate anomer anion was readily generated in situ (according to the Ando and Ishihira methods, ${ }^{[14]}$ ) and fully converted under our conditions to the $\beta$-selenoglycoside $\mathbf{3 a}$ in $95 \%$ yield as a single $\beta$-anomer $\left(J_{1,2}=9 \mathrm{~Hz}\right)$. Decreasing the catalyst loading from $10 \mathrm{~mol} \%$ to $5 \mathrm{~mol} \%$ led to $\mathbf{3 a}$ in a slightly lower yield ( $81 \%$ yield, entry 2 ). With these encouraging results, we continued the optimization of the reaction conditions with respect to other parameters (base, solvent, reaction time, amount of the reagents). We confirmed that $\mathrm{Cs}_{2} \mathrm{CO}_{3}$ is the base of choice since the use of $\mathrm{CsF}$ or $\mathrm{NaOAc}$ produced the desired selenoglycoside $\mathbf{3 a}$ in $83 \%$ and $65 \%$ yields, respectively. Moreover, performing the cross-coupling in other polar solvents such as dioxane, DCE or DMF produced the desired product 3a in yields ranging from $83 \%$ to $95 \%$ (entries 5-7). Finally, performing the reaction for $1 \mathrm{~h}$ furnished 3a in only $80 \%$ yield (entry 8 ), while $95 \%$ yield was obtained when the reaction time adjusted to $2 \mathrm{~h}$ (entry 9). A control experiment showed that the PdG3-XantPhos precatalyst was essential for this coupling since no reaction occurred when $\mathrm{Pd}(\mathrm{OAc})_{2}(10$ mol\%) and XantPhos (10 mol\%) were used (see SI).

With these results in hand, we investigated the scope for this coupling by varying the nature of the aryl iodide partner 2 and the $p$-methylbenzoylselenyl glycosides 1a-g (Scheme 1). Pleasantly, this coupling proceeded cleanly in excellent yields. Various electron- rich and electron-deficient aryl iodides having para- and meta-substitution effectively underwent reaction with $\beta$ - $p$-methylbenzoylselenoglycoside 1a in yields up to $99 \%$ (products 3a-q). Interestingly, this coupling tolerates various reactive functional groups such as isopropyl (3f), nitrile (3h), halogens (3j), nitro (3k), aldehyde (3l), ketone (3o) and ester (3m, $\mathbf{n}$ and 3p, q). Moreover, the coupling is not limited to aryl halides, but works also with halogenated alkenes such as $E$ - $\beta$ styryl iodide (compound $\mathbf{3 g}$ ). In addition, the reaction of $\mathbf{1 a}$ with heteroaryl halides such as 4-iodopyridine and 5-iodoindole have been performed successfully, furnishing 3r-s in $87 \%$ and $85 \%$ yield, respectively. Ortho-substituted aryl iodides such as 
ortho-methoxyl iodobenzene, ortho-cyano iodobenzene and ortho-CF3 iodobenzene were not effective coupling partners

Scheme 1 Scope of Coupling of $\beta-p$ methylbenzoylselenoglycoside $\mathbf{1 a}$ with Halo(hetero)arenes and Alkenyl Halides 2

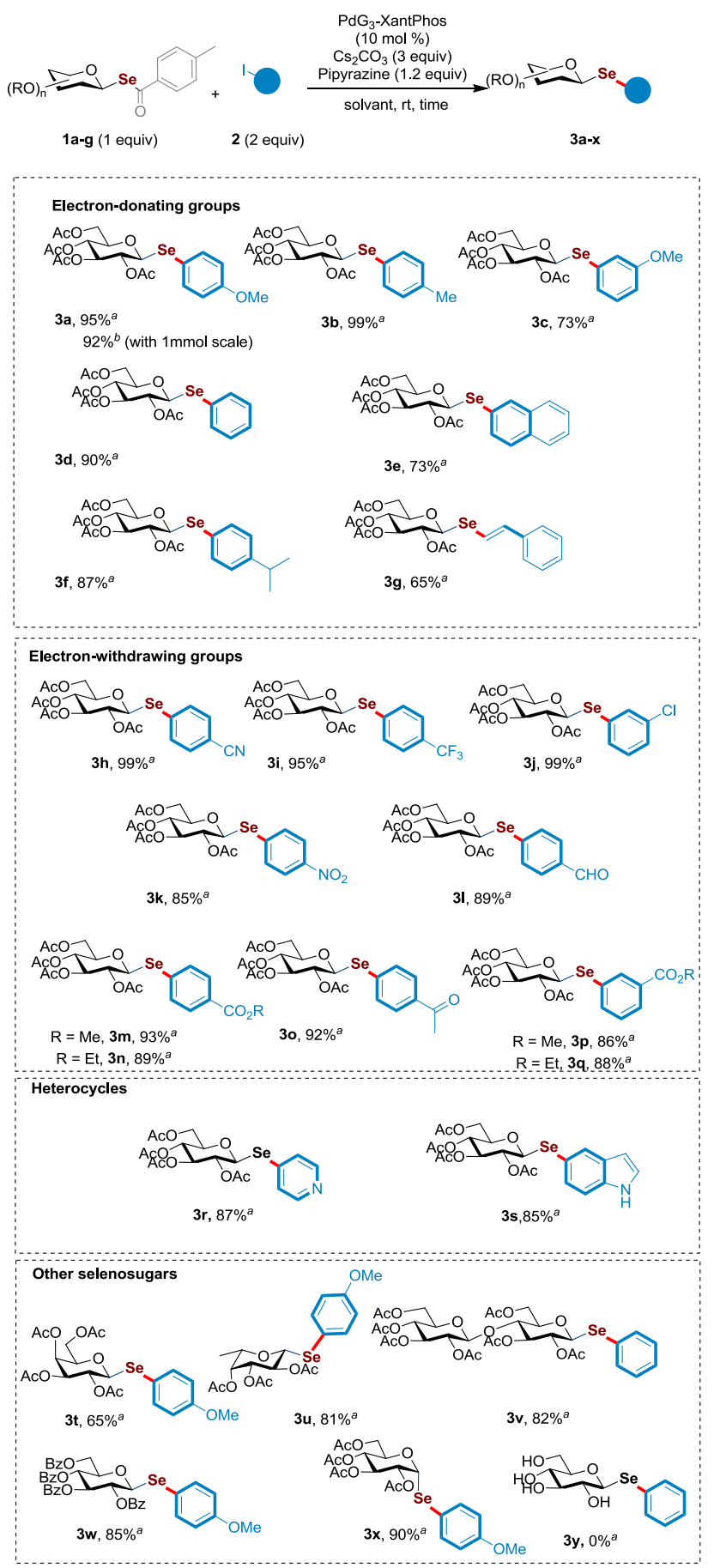

Reaction conditions: A sealable tube was charged with $\beta-p$ methylbenzoylselenoglycoside 1 a ( 1 equiv, $0.1 \mathrm{mmol}), 2$ (2 equiv), PdG3-XantPhos precatalyst (10 mol \%), piperazine (1.2 equiv), $\mathrm{Cs}_{2} \mathrm{CO}_{3}$ (3 equiv) in dry and degassed THF (0.1 M) under Ar for $2 \mathrm{~h} .{ }^{a}$ Yield of isolated product.

probably due to the hindrance effect, implying that the oxidative addition of aryl iodides to palladacycle is not facile. Finally, this method tolerates other selenosugars such selenogalactose, selenofucose and selenocellobiose or $\mathrm{OBz}$ - protected selenoglucose which were successfully coupled with $\mathbf{2 a}$ or $\mathbf{2 d}$ to give $\beta$-Se-glycosides 3t-v in good yields. Besides $p$ -

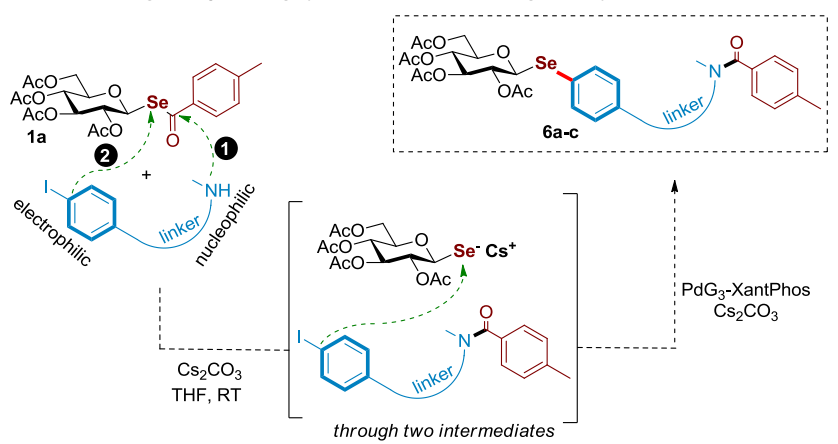

Figure 3. Strategy for the trapping of the $p$-methylbenzoyl group of 1a by using a double action (electrophilic-nucleophilic) of the partner

methylbenzoylselenyl $\beta$-glycosides $\alpha$-glycoside is also an effective substrate for this methodology giving the desired Seglycosides $\mathbf{3 x}$ in excellent yield and with exclusive $\alpha$ selectivity. Of note attempts to react the unprotectd selenoglycoside failed: $\mathbf{3 y}$ was never detected and only the degradation of starting materials was observed.

In a next part of this study, we focused our attention on demonstrating whether our cross-coupling could be employed with functionalized aryl iodides bearing a secondary amino group (Figure 3). We may assume that these bis-electrophilic nucleophilic partners could be involved in two concomitant reactions: at first by a nucleophilic action, the secondary amine such as piperazine, traps the $p$-methylbenzoyl group of the selenoglycoside 1a and generates the anomeric selenolate anion. Then, this later will react with the electrophilic part $(\mathrm{C}-\mathrm{I}$ bond) via the $\mathrm{Pd}$-catalzyed $\mathrm{Se}-\mathrm{C}\left(\mathrm{sp}^{2}\right)$ bond forming reaction. By this way, all the atoms of the reactants will be incorporated into the final desired products, resulting in high atom economy and environmental process which avoid the generation of wastes.

Scheme 2 Scope of Coupling of 1a with Functionalized Aryl iodides Bearing a Secondary Amino Group 5a-c

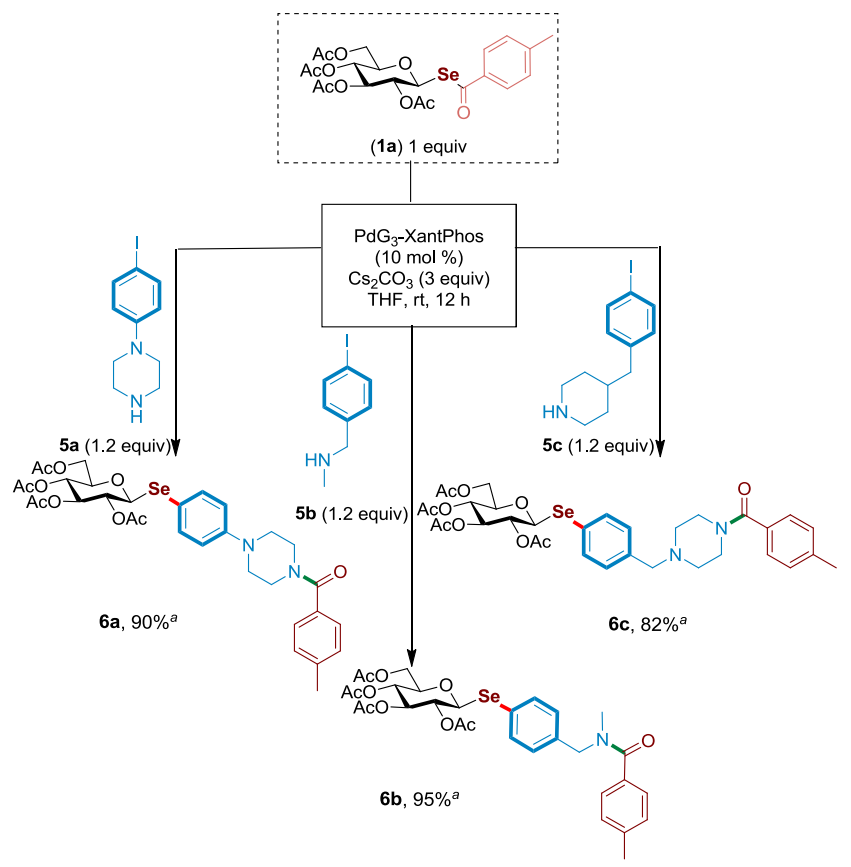

Reaction conditions: A sealable tube was charged with $\beta-p$ methylbenzoylselenoglycoside 1a (1 equiv, $0.1 \mathrm{mmol})$, 5a-c $(1.2$ equiv), PdG3-XantPhos precatalyst (10 mol \%), $\mathrm{Cs}_{2} \mathrm{CO}_{3}$ (3 equiv) in 
dry and degassed THF (0.1 M) under Ar for 12 h. ${ }^{a}$ Yield of isolated product 6a-c.

As shown in Scheme 2, the proof-of-concept of this green process was demonstrated by coupling of bis-electrophilicnucleophilic partners 5a-c with pmethylbenzoylselenoglycoside $\mathbf{1 a}$ in the presence of PdG3XantPhos (10 mol\%), $\mathrm{Cs}_{2} \mathrm{CO}_{3}$ (3 equiv) in THF at room temperature. Under these conditions, the synthesis of phenylpiperazine functionnalized selenoglycosides $\mathbf{6 a}$ and $\mathbf{6 c}$ were achieved with $90 \%$ and $82 \%$ yields, respectively. This finding is of high interest since piperazine is known as one of the most promising ring displaying various biological activities for the treatmentof Parkinson's disease, Alzheimer's disease and depression. ${ }^{[18]}$ In addition, this methodology led to the synthesis of the $N$-benzyl selenoglycoside $6 \mathbf{b}$ in $\operatorname{good} 95 \%$ yield (Scheme 2).

In summary, we have shown that anomeric selenolate anions are competent nucleophilic partners in the Pd-catalyzed crosscoupling reactions. To our best of our knowledge the $\mathrm{C}\left(\mathrm{sp}^{2}\right.$ )-Se bond of (hetero)aryl selenoglycosides was formed, for the first time, directly by a Pd-catalyzed cross-coupling of selenosugar with aryl halides at room temperature. Because of the mildness of the reaction conditions, this protocol tolerates a wide range of functional groups and proceeds in good to excellent yields. In addition, a variety of selenosugars could be used. This method opens news opportunities for using glycosyl selenolate in synthetic methodology and medicinal chemistry.

\section{ASSOCIATED CONTENT}

\section{Supporting Information}

The Supporting Information is available free of charge on the ACS Publications website.

Experimental procedures, spectroscopic data and NMR spectra of new compounds.

\section{AUTHOR INFORMATION}

\section{Corresponding Author}

*E-mail: samir.messaoudi@u-psud.fr

\section{Author Contributions}

The manuscript was written through contributions of all authors. / All authors have given approval to the final version of the manuscript.

\section{Notes}

The authors declare no competing financial interest.

\section{ACKNOWLEDGMENTS}

Authors acknowledge support of this project by CNRS, University Paris-Sud, ANR (CarNuCat, ANR-15-CE29- 0002), and by la Ligue Contre le Cancer through an Equipe Labellisée 2014 grant. We also thank the China Scholarship Council for a fellowship (CSC) to Mingxiang Zhu.

\section{REFERENCES}

(1) (a) F. Zhu, S. O’Neill, J. Rodriguez, M. A. Walczak. Stereoretentive Reactions at the Anomeric Position: Synthesis of Selenoglycosides. Angew. Chem., Int. Ed. 2018, 57, 7091; (b) Y. Guan, S. D. Townsend. Metal-Free Synthesis of Unsymmetrical Organoselenides and Selenoglycosides. Org. Lett. 2017, 19, 5252; (c) K. Bijian, Z. Zhang, B. Xu, S. Jie, B. Chen, S. Wan, J. Wu, T. Jiang, M. A. Alaoui-Jamali. Synthesis and biological activity of novel organoselenium derivatives targeting multiple kinases and capable of inhibiting cancer progression to metastases. Eur. J. Med. Chem. 2012 , 48, 143; (d) O. Boutureira, G. J. L. Bernardes, M. FernándezGonzález, D. C. Anthony, B. G. Davis. Selenenylsulfide-Linked Homogeneous Glycopeptides and Glycoproteins: Synthesis of Human "Hepatic Se Metabolite A". Angew. Chem. Int. Ed. 2012, 51, 1432; (e) K. Sidoryk, L. Rarova, J. Oklestkova, Z. Pakulski, M. Strnad, P. Cmoch, R. Luboradzki. Synthesis of 28a-homoselenolupanes and 28a-homoselenolupane saponins. Org. Biomol.Chem. 2016, 14, 10238; (f) C. Kona, J. Shimabukuro, M. Kiso, H. Ando. Organoselenium Compounds in Biology and Medicine:Synthesis, Carbohydrate-derived Organoselenium Compounds: Synthesis and Application in the Structural Analysis of Biomolecules, C. Kona, J. Shimabukuro, M. Kiso, H. Ando, 2017, 223-253.

(2) A. W. McDonagh, M. F. Mahon, P. V. Murphy. Lewis Acid Induced Anomerization of Se-Glycosides. Application to Synthesis of $\alpha$-Se-GalCer. Org. Lett. 2016, 18, 552.

(3) (a) N. Kostlanova, E. P. Mitchell, H. Lortat-Jacob, S. Oscarson, M. Lahmann, N. Gilboa-Garber, G. Chambat, M. Wimmerová, A. J. Imberty. The Fucose-binding Lectin from Ralstonia solanacearum. Biol. Chem. 2005, 280, 27839; (b) T. Suzuki, H. Makyio, H. Ando, N. Komura, M. Menjo, Y. Yamada, A. Imamura, H. Ishida, S. Wakatsuki, R. Kato, M. Kiso. Expanded potential of selenocarbohydrates as a molecular tool for X-ray structural determination of a carbohydrate-protein complex with single/multi-wavelength anomalous dispersion phasing. Bioorg. Med. Chem. 2014, 22, 2090; (c) J. Shimabukuro, H. Makyio, T. Suzuki, Y. Nishikawa, M. Kawasaki, A. Imamura, H. Ishida, H. Ando, R. Kato, M. Kiso. Synthesis of seleno-fucose compounds and their application to the Xray structural determination of carbohydrate-lectin complexes using single/multi-wavelength anomalous dispersion phasing. Bioorg. Med. Chem. 2017, 25, 1132.

(4) (a) C. Hamark, J. Landstrom, G. Widmalm. SEAL by NMR: Glyco-Based Selenium-Labeled Affinity Ligands Detected by NMR Spectroscopy. Chem. -Eur. J. 2014, 20, 13905; (b) I. Perez-Victoria, O. Boutureira, T. D. W. Claridge, B. G. Davis. Glycosyldiselenides as lectin ligands detectable by NMR in biofluids. Chem. Commun. 2015, 51, 12208; (c) J. Uzawa, J. Shimabukuro, T. Suzuki, A. Imamura, H. Ishida, H. Ando, Y. Yamaguchi. J $\left({ }^{77} \mathrm{Se},{ }^{1} \mathrm{H}\right)$ and $\mathrm{J}\left({ }^{77} \mathrm{Se},{ }^{13} \mathrm{C}\right)$ couplings of seleno-carbohydrates obtained by ${ }^{77} \mathrm{Se}$ satellite ${ }^{1} \mathrm{D}{ }^{13} \mathrm{C}$ spectroscopy and ${ }^{77} \mathrm{Se}$ selective HR-HMBC spectroscopy. Magn. Reson. Chem. 2018, 56, 836; (d) T. Suzuki, C. Hayashi, N. Komura, R. Tamai, J. Uzawa, J. Ogawa, H. Tanaka, A. Imamura, H. Ishida, M. Kiso, Y. Yamaguchi, H. Ando. Synthesis and Glycan-Protein Interaction Studies of Se-Sialosides by ${ }^{77} \mathrm{Se}$ NMR. Org. Lett. 2019, $21,6393$.

(5) Y. Kobayashi, Y. Ogra, K. Ishiwata, H. Takayama, N. Aimi, K. T. Suzuki. Selenosugars are key and urinary metabolites for selenium excretion within the required to low-toxic range. Proc. Natl. Acad. Sci. USA 2002, 99, 15932.

- (6) A. W. McDonagh, M. F. Mahon, P. V. Murphy. Lewis Acid Induced Anomerization of Se-Glycosides. pplication to Synthesis of $\alpha$-Se-GalCer. Org. Lett. 2016, 18, 552.

(7) K. Bijian, Z. Zhang, B. Xu, S. Jie, B. Chen, S. Wan, J. Wu, T. Jiang, M. A. Alaoui-Jamali. Synthesis and biological activity of novel organoselenium derivatives targeting multiple kinases and capable of inhibiting cancer progression to metastases. Eur. J. Med. Chem. 2012, $48,143$.

(8) S. André, K. E. Kövér, H. Gabius, L. Szilágyi. Thio- and selenoglycosides as ligands for biomedically relevant lectins: Valency-activity correlations for benzene-based dithiogalactoside clusters and first assessment for (di)selenodigalactosides. Bioorg. Med. Chem. Lett. 2015, 25, 931.

(9) Z. Kónya, B. Bécsi, A. Kiss, I. Tamás, B. Lontay, L. Szilágyi, K. E. Kövér, F. Erdődi. Aralkyl selenoglycosides and related selenosugars in acetylated form activate protein phosphatase-1 and 2A. Bioorg. Med. Chem, 2018, 26, 1875.

(10) (a) Z. J. Witczak, S. Czernecki. Synthetic Applications of Selenium-Containing Sugars. Adv. Carbohydr. Chem. Biochem. 1998, 53, 143; (b) A. V. Demchenko. Handbook of Chemical Glycosylation: Advances in Stereoselectivity and Therapeutic Relevance. WileyVCH Verlag, Weinheim, Germany, 2008. For examples, see: (c) S. Yamago, K. Kokubo, H. Murakami, Y. Mino, O. Hara, J.-I. Yoshida. 
Glycosylation with telluroglycosides. Stereoselective construction of $\alpha$ - and $\beta$-anomer. Tetrahedron Lett. 1998, 39, 7905; (d) S. Yamago, T. Yamada, O. Hara, H. Ito, Y. Mino, J.-I. Yoshida. A New, Iterative Strategy of Oligosaccharide Synthesis Based on Highly Reactive $\beta$ Bromoglycosides Derived from Selenoglycosides. Org. Lett. 2001, 3, 3867; (e) S. Yamago, K. Kokubo, O. Hara, S. Masuda, J.-i. Yoshida. Electrochemistry of Chalcogenoglycosides. Rational Design of Iterative Glycosylation Based on Reactivity Control of Glycosyl Donors and Acceptors by Oxidation Potentials. J. Org. Chem. 2002, 67, 8584; (f) S. Valerio, A. Iadonisi, M. Adinolfi, A. Ravidà. Novel Approaches for the Synthesis and Activation of Thio- and Selenoglycoside Donors. J. Org. Chem. 2007, 72, 6097; (g) S. Tsegay, R. J. Williams, S. Williams. Synthesis of glycosyl fluorides from thio-, seleno-, and telluroglycosides and glycosyl sulfoxides using aminodifluorosulfinium tetrafluoroborates. J. Carbohydr. Res. 2012, 357, 16; (h) M. Spell, X. Wang, A. E. Wahba, E. Conner, J. Ragains. An $\alpha$-selective, visible light photocatalytic glycosylation of alcohols with selenoglycosides. Carbohydr. Res. 2013, 369, 42; (i) R. R. France, R. G. Compton, B. G. Davis, A. J. Fairbanks, N. V. Rees, J. D. Wadhawan. Selective electrochemical glycosylation by reactivity tuning. Org. Biomol. Chem. 2004, 2, 2195; (j) I. Cumpstey, D. J. Crich. Photoinitiated Glycosylation at $350 \mathrm{~nm}$. Carbohydr. Chem. 2011, 30, 469; (k) R. M. van Well, T. S. Kaerkkaeinen, K. P. R. Kartha, R. A. Field. Contrasting reactivity of thioglucoside and selenoglucoside donors towards promoters: implications for glycosylation stereocontrol. Carbohydr. Res. 2006, 341, 1391; (1) R. V. Stick, D. M. G. Tilbrook, S. J. Williams. The Selective Activation of Telluro- over Seleno- $\beta$-D-glucopyranosides as Glycosyl Donors: a Reactivity Scale for Various Telluro, Seleno and Thio Sugars. Aust. J. Chem. 1997, 50, 237.

(11) (a) S. Czernecki, D. Randriamandimby. Selenoglycosides $5 .{ }^{1}$ Stereocontrolled Synthesis of Seleno-Disaccharides. J. Carbohydr. Chem. 1996, 15, 183; (b) K. Ikeda, Y. Sugiyama, K. Tanaka, M. Sato. Use of Phenyl 2- $\alpha$-Selenoglycosides of N-Acetylneuraminic Acid as a Glycosyl Donor for the Glycosylation Reactions. Bioorg. Med. Chem. Lett. 2002, 12, 2309; (c) D. Crich, D. -H. Suk, S. Sun. Highly diastereoselective radical cyclization of a glucose-derived enol ether radical cation/phosphate anion pair. Tetrahedron: Asymm. 2003, 14, 2861; (d) S. Knapp, E. Darout. New Reactions of Selenocarboxylates. Org. Lett. 2005, 7, 203; (e) Y. Guan, S. D. Townsend. Metal-Free Synthesis of Unsymmetrical Organoselenides and Selenoglycosides. Org. Lett. 2017, 19, 5252; (f) Y. Guan, S. D. Townsend. Metal-Free Synthesis of Unsymmetrical Organoselenides and Selenoglycosides, Org. Lett. 2017, 19, 5252.

(12) (a) D. M. Gordon, S. J. Danishefsky. Displacement reactions of a 1, 2-anhydro- $\alpha$-d-hexopyranose: installation of useful functionality at the anomeric carbon. Carbohydr. Res. 1990, 206, 361; (b) V. D. Bussolo, A. Fiasella, F. Balzano, G. U. Barretta, P. Crotti. Stereoselective Synthesis of $\beta$-Phenylselenoglycosides from Glycals and Rationalization of the Selenoglycosylation Processes. J. Org. Chem. 2010, 75, 4284.

(13) (a) S. Czernecki, D. Randriamandimby. Azidophenylselenylation of protected glycals. Tetrahedron Lett. 1993, 34, 7915; (b) F. Santoyo-Gonzalez, F. G. Calvo-Flores, P. GarciaMendoza, F. Hernandez-Mateo, J. Isac-Garcia, R. Robles-Diaz. Synthesis of phenyl 2-azido-2-deoxy-1-selenoglycosides from glycals. J. Org. Chem. 1993, 58, 6122; (c) S. Czernecki, E. Ayadi, D. Randriamandimby. Seleno glycosides. 2. Synthesis of Phenyl 2-(NAcetylamino)- and 2-Azido-2-deoxy-1-seleno-.alpha.-Dglycopyranosides via Azido-phenylselenylation of Diversely Protected Glycals. J. Org. Chem. 1994, 59, 8256; (d) Y. V. Mironov, A. A. Sherman, N. E. Nifantiev. Homogeneous azidophenylselenylation of glycals using $\mathrm{TMSN}_{3}-\mathrm{Ph}_{2} \mathrm{Se}_{2}-\mathrm{PhI}(\mathrm{OAc})_{2}$ Tetrahedron Lett. 2004, 45, 9107; (e) E. Bedini, D. Esposito, M. Parrilli. A Versatile Strategy for the Synthesis of N-Acetylbacillosamine-Containing Disaccharide Building Blocks Related to Bacterial O-Antigens. Synlett 2006, 2006, 825

(14) (a) Y. Kawai, H. Ando, H. Ozeki, M. Koketsu, H. Ishihara. A Facile Method for $\beta$-Selenoglycoside Synthesis Using $\beta$-pMethylbenzoyl Selenoglycoside as the Selenating Unit. Org. Lett. 2005, 7, 4653; (b) M. Nanami, H. Ando, Y. Kawai, M. Koketsu, H. Ishihara. Stereoselective synthesis of various $\alpha$-selenoglycosides using in situ production of $\alpha$-selenolate anion. Tetrahedron Lett. 2007, 48,1113 .

(15) Fore a recent review, see: (a) N. Ibrahim, M. Alami, S. Messaoudi. Recent Advances in Transition Metal-Catalyzed Functionalization of 1-Thiosugars. Recent Advances in Transition-MetalCatalyzed Functionalization of 1-Thiosugars. Asian. J. Org. Chem. 2018, 7, 2026; (b) E. Brachet, J.-D. Brion, S. Messaoudi, M. Alami. Stereoselective Palladium-Catalyzed Alkenylation and Alkynylation of Thioglycosides. Adv. Synth. Catal. 2013, 355, 2627; (c) E. Brachet, J. -B. Brion, S. Messaoudi, M. Alami. Palladium-Catalyzed CrossCoupling Reaction of Thioglycosides with (Hetero)aryl Halides. Adv. Synth. Catal. 2013, 355, 477; (d) A. Bruneau, M. Roche, A. Hamze, J.-D. Brion, M. Alami, S. Messaoudi. Stereoretentive PalladiumCatalyzed Arylation, Alkenylation, and Alkynylation of 1-Thiosugars and Thiols Using Aminobiphenyl Palladacycle Precatalyst at Room Temperature. Chem. Eur. J. 2015, 21, 8375; (e) R. A. A. AL-Shuaeeb, D. Montoir, M. Alami, S. Messaoudi. Synthesis of $(1 \rightarrow 2)-$ S-Linked Saccharides and S-Linked Glycoconjugates via a Palladium-G3XantPhos Precatalyst Catalysis. J. Org. Chem. 2017, 82, 6720; (f) N. Probst, R. Lartia, O. Théry, M. Alami, E. Defrancq, S. Messaoudi. Efficient Buchwald-Hartwig-Migita Cross-Coupling for DNA Thioglycoconjugation. Chem. Eur. J. 2018, 24, 1795; (g) D. Montoir, M. Amoura, Z. E.-A. Ababsa, T. M. Vishwanath, E. Yen-Pon, V. Robert, M. Beltramo, V. Piller, M. Alami, A. Aucagne, S. Messaoudi. Synthesis of Aryl-Thioglycopeptides Through Chemoselective PdMediated Conjugation. Chem. Sci., 2018, 9, 8753. (h) S. Benmahdjoub, N. Ibrahim, B. Benmerad, M. Alami, S. Messaoudi. OnePot Assembly of Unsymmetrical Biaryl Thioglycosides through Chemoselective Palladium-Catalyzed Three-Component Tandem Reaction. Org. Lett. 2018, 20, 4067; (i) M. Zhu, G. Dagousset, M. Alami, E. Magnier, S. Messaoudi. Ni/Photoredox-Dual-Catalyzed Functionalization of 1-Thiosugars. Org. Lett. 2019, 21, 5132.

(16) (a) M. S. Oderinde, M. Frenette, D. W. Robbins, B. Aquila, J. W. Johannes. J. Am. Chem. Soc. 2016, 138, 1760; (b) C. Valente, M. Pompeo, M. Sayah, M. G. Organ. Org. Process Res. Dev. 2014, 18, 180.

(17) A. Bruneau, M. Roche, A. Hamze, J. -D. Brion, M. Alami, S. Messaoudi. Stereoretentive Palladium-Catalyzed Arylation, Alkenylation, and Alkynylation of 1-Thiosugars and Thiols Using Aminobiphenyl Palladacycle Precatalyst at Room Temperature. Chem. Eur. J. 2015, 21, 8375.

(18) (a) C. Meher, A. Rao, M. Omar Piperazine-pyrazine and their multiple biological activities, Asian J. Pharm. Sci. Res., 2013, 3, 4360; (b) A. L. Johnstone, G.W. Reierson, R. P. Smith, J. L. Goldberg, V.P. Lemmon, J. L. Bixby, A chemical genetic approach identifies piperazine antipsychotics as promoters of CNS neurite growth on inhibitory substrates, Mol. Cell Neurosci., 2012), 50, 125-135, (c) B. K. Sheetal, A. K. Mantha, V. Kumar, biological evaluation and molecular modeling studies of phenyl-/benzhydrylpiperazine derivatives as potential MAO inhibitors, Bioorg. Chem. 2018, 77, 252-262 